\title{
Bank Competition, Stock Market and Economic Growth in Ghana
}

\author{
Stephen Asante \\ Department of Accounting and Finance, School of Business \\ University of Cape Coast, Ghana \\ E-mail: sasante44@yahoo.com \\ Daniel Agyapong \\ Department of Management Studies, School of Business \\ University of Cape Coast, Ghana \\ E-mail: agyapongdan@yahoo.co.uk \\ Anokye M. Adam (Corresponding author) \\ Department of Accounting and Finance, School of Business \\ University of Cape Coast, Ghana \\ E-mail: ano77chie@yahoo.co.uk
}

Received: July 12, $2011 \quad$ Accepted: September 5, $2011 \quad$ Published: November 21, 2011

doi:10.5430/ijba.v2n4p33

URL: http://dx.doi.org/10.5430/ ijba.v2n4p33

\begin{abstract}
The paper empirically investigates the relationship between bank competition, stock market and economic growth in Ghana using time series data for the period between 1992 and 2009. Short and long run relationship were established within the frameworks of Granger causality and the Autoregressive Distributed Lag (ARDL)/ Dynamic Ordinary Least Square (OLS) approach respectively. It was found that bank competition and stock market development granger cause economic growth in Ghana. Also, in the long run, banking competition is good for economic growth. However, there is a disproportionate response of economic growth to stock market development. It is recommended that policy to promote banking competition should be vigorously pursued.
\end{abstract}

Keywords: Bank Competition, Stock Market, Cointegration, ARDL

\section{Introduction}

The level of financial market development has impact on the economy of a nation. The finance-growth nexus theory indicates that financial development may bring about a fall in intermediation margins, search cost and efficiency in financial markets. The effective functioning of a country's financial system is said to enhance the smooth implementation of its macroeconomic policies. The levels of banking development and stock market liquidity each are found to have impact on the economy of a country.

It is of this view that most African countries began to implement financial sector reforms as part of their broad market reforms that took place in the late 1980s. The major goals of these reforms are to build more efficient, competitive robust and deeper financial markets. As was posited by Kasekende (2007), the reforms have improved the financial sector considerably across the sub-region - enhancing bank competition as well as facilitating the development of the capital market.

The reforms saw the deregulation of the financial sub-sector in most of these economies through privatisation of state-owned banks, the influx of private banks as well as the registration of non-bank financial institutions. The era also witnessed the development of new products by banks and the capital market as well as the use of new processes in financial service delivery.

Some other important outcome of the financial sector reorganisation is increased bank competition and the unification of interest rate in the sub-region leading to rise in nominal deposit and lending rates. The banking systems in most African 
countries are concentrated but are showing signs of becoming more competitive. However, some concentration is necessary and inevitable as it aids banks to achieve some economies of scale and scope. Concentration is often necessary due to the nature of local infrastructure in most of these economies. Although the number of competitors in a banking market rises with the population and the economy's size, the case is different in some of the African countries. Also competition in the banking sector is further intensified by the presence of foreign banks. Such a phenomenon is expected to deepen the financial system introducing strong business practices, technology, products and prudent risk management systems which would bring about needed economic benefits. More so, development in the capital market- an avenue to raise foreign capital and venture capital for financing projects- could play a significant role in an economies growth as they compliment the money market activities. So if the equity markets in various African countries are well developed, it could play a pivotal role in their developmental agenda.

The neo-classical growth model explains the interaction between financial markets and economic growth in three different ways. First, growth depends on capital accumulation - increasing the stock of capital goods to expand productive capacity. Also, net investment and the need for sufficient saving to finance investment through financial deepening may lead to growth; and finally, higher savings - postponing consumption to finance increased allocation of resources towards investment (Solow, 1956). Similarly, the endogenous growth theory posit that government policy to increase capital or foster right kinds of investment in physical capital can permanently raise economic growth (Romer, 1986; Lucas, 1988). However, traditional growth theorists, for instance, believe that there is no correlation between stock market development and economic growth because of the presence of level effect and rate effect.

Yet, the assessment model of stock prices and the wealth effect provide hypothetical explanation for stock prices to be proceeded as an indicator of output (Shahbaz, Ahmed and Ali, 2008). According to wealth effect, changes in stock prices cause variation in the real economy.

Similarly, empirical evidence on the influence of activities of two of the financial institutions (banks and stock exchange) on economic growth of a country as reported in studies in most developed economies is largely inconsistent. But, little work has been done in emerging markets, especially in the economies such as Ghana. More so, whereas some contemporary empirical work such as King and Levine (1993), Demirgue-Kunt and Maksimovic (1998), Levine, Loayza and Beck (2002), Ahmad and Malik (2009), showed that broader, deeper financial markets are strongly associated with economic growth, others are of contrary view. Pagano (1993) and Guzman (2000) argued theoretically that banking market power reduces equilibrium credit, thereby generating a negative effect on economic growth. But Peterson and Rajan (1995), Shaffer (1998), Cao and Shi (2000) were of the contrary.

Also, Singh (1997) contended that stock markets are not necessary institutions for achieving high levels of economic development. Instead, they are agents that harm economic development due to their susceptibility to market failure, which is often manifested in the volatile nature of stock market in many developing countries (Singh, 1997). The volatility of stock market may reduce the ability of the public to supervise on a company's investment (Bhide, 1993). In addition, the public may increase investment returns by speculating in the stock market; thus, the stock market development may be unfavourable to the economic growth. Obstfeld (1994) indicates that high financial market liquidity may increase investment returns and thus decrease saving rate due to substitution effect and income effect, which is unfavourable to economic growth. So do bank competition and stock market development have an effect on the economic growth?

The present study dives into the debate by examining the effect bank competition and stock market development on economic growth of small and open economy like Ghana. The studies specifically looks at the channel through which bank competition and stock market promote growth. The study makes important contribution by deviating from general proxy for banking competition and introduces new proxy which combines number of banks with year in existence. The results from the long run estimate shows that banking competition is good for economic growth which is an indication of healthy competition in Ghanaian banking sector. The implication of our finding is that policies that expand and improve competition in banking sector should be vigorously pursued.

The rest of the paper is organise as follows: section two looks at the literature review, section three the methodology, Empirical Results and Analysis in section four and Concluded in section five

\section{Literature Review}

\subsection{Theoretical Framework}

The theoretical supposition that financial markets matter for economic growth is old which has been buttressed by the neo-classical growth theory (Shaw, 1973). Solow (1956) posits that growth depends on capital accumulation - increasing the stock of capital goods to expand productive capacity; net investment and the need for sufficient saving to finance 
investment and higher savings - postponing consumption to finance increased allocation of resources towards investment. From this theory, it is realized that a combination of capital deepening and technological improvement explains major trends in economic growth. Similarly, endogenous growth theory says that government policy to increase capital or foster right kinds of investment in physical capital can permanently raise economic growth. Also by the finance-growth nexus theory, financial development might reduce the intermediation margins and search costs, mobilise savings and raise capital productivity. In view of this, efficient and deeper financial system is expected to mobilise savings, channel savings into productive investments, improve the efficiency and productivity of investments, promote the integration of the domestic economy into the global financial system and enhance smooth implementation of macroeconomic policies (Kasekende, 2007).

The contemporary empirical work is also inspired by the previous contributions of Goldsmith (1969), Gurley and Shaw (1967), and Mckinnon (1973). The revival of this literature in the last decade was inspired in large part by the fact that extensive and reliable cross country data sets had become available in the 1980s and by the lingering theoretical debate about the actual importance of financial markets for real economic activity. The work that followed, King and Levine (1993), Demirguc-Kunt and Maksimovic (1998), Levine and Zervos (1998), Levine, Loayza and Beck (2002) and Cetorelli (2003) has provided robust empirical evidence that broader, deeper financial markets are strongly associated causally - with better prospects for future economic growth.

Beck (2008) in his work "econometrics of finance and growth,” proposed three different approaches to analysing the effect of financial markets on economic growth. First, the standard cross-country ordinary least square (OLS) analysis that builds on augmented Baro growth regression. With this approach data for each country is averaged over the sample period. This approach has been used by Levine and Zervos (1998) and De Gregorio and Guidotti (1995) to establish a relationship between stock markets and or banking and economic growth. However this method has been criticised for lack of consistency and efficiency. It does not use the variation in the explanatory variables that is correlated with the instrument and therefore uses more information. In view of the weakness associated with the OLS method, some researchers resort to the use of the instrumental variable (IV) approach. This uses the Two-Stage-Least Squares Estimator (TSLS) which is found to be consistent and efficient. It can also be derived as a General Method of Moments (GMM) estimator that minimizes a set of orthogonality conditions (Hansen, 1982, Beck, 2008). But as was identified by Hayashi (2000) GMM estimator relies on asymptotic characteristics and therefore suffers from a finite-sample bias as the optimal weighting matrix is a function of fourth moments

Meanwhile, instrumental variable approach has its peculiar limitations (Beck, 2008). First, cross-country studies using cross-sectional instrumental variable regressions typically control only for the endogeneity and measurement error of financial development, but not of other explanatory variables entering the growth regressions. Second, in the presence of country-specific omitted variables, the lagged dependent variable is correlated with the error term if it is not instrumented. In view of this, researchers have therefore resorted to the use dynamic panel regressions. Yet the dynamic panel method has been found to be bias base on country specific effects. Hence the need to first-differencing the regression equation to eliminate the country-specific effect (Arellano and Bond, 1991).

Also there is the use of time series especially for higher-frequency data, often limited to one or a few countries. The concept of causality is the main differences between the time series approach and the cross-country approach. The main differences are that the time-series approach relies on higher-frequency data, mostly yearly, to gain econometric power, while the cross-country approach typically utilizes multi-year averages. Further, the time-series approach relaxes the somewhat restrictive assumption of the finance - growth relationship being the same across countries and allows country heterogeneity of the finance-growth relationship; most studies therefore focus their analysis on a few countries with long time-series data. The time-series approach also directly addresses biases introduced by the persistence and potential unit root behaviour of financial development. Also, different causality concepts underlie the two approaches. The time-series approach relies on the concept of Granger causality, as first developed by Granger (1969).

\subsection{Bank Competition and Economic Growth}

Though there do not seem to be direct relationship between bank competition and economic growth of a country, recent empirical evidence suggests that bank competition fosters industrial growth (Claessens and Laeven, 2005) and helps in particular the financing of private and small firms that are perceived to be engine of economic growth (Cetorelli and Strahan, 2006; Giannetti and Ongena, 2005). According to Champonnois (2007) in most cases, the economy experiences a vicious circle in which the numbers of firms and banks eventually increase and converge to equilibrium with high aggregate investment and high welfare. In some cases however, when the initial numbers of firms and banks is very low, the economy experiences a vicious circle in which banks and firms exit and aggregate investment eventually decreases. It has been shown theoretically that the degree of competition in the financial sector can affect the access of firms to 
external financing (Vives, 2001). Moreover, Champonnois (2007) posit that if the number of banks increases, there is more bank competition and the profit of entrepreneurs' increases.

As Claessens and Laeven (2005) puts it, less competitive systems may lead to easier access to external financing because, with more market power, banks are more inclined to invest in information acquisition and relationships with borrowers. However, when banking systems are less competitive, hold-up problems may lead borrowers to be less willing to enter such relationships, thereby lowering the effective demand for external financing. Furthermore, less-competitive banking systems can be more costly and exhibit a lower quality of services, thereby lowering the effective demand for external financing and thus encouraging less growth. These effects may further vary by the degree of competition in the country's overall financial sector -the degree of hold-up problems in the system may vary with the availability of financing options outside of the banking system such as from capital markets. In effect, the theoretical prediction of the effects of bank competition on growth is unclear Claessens and Laeven, 2003; Cetorelli and Strahan, 2006). Though there is a relationship between bank competition and economic growth, the direction of this relationship, however, is unclear, hence worth further investigating.

Also empirical studies have concentrated on looking at the effects of regulations and specific structural or other factors on banking performance; applying structural competition test to banking systems, investigating how market structure, entry and activity regulations, and the presence of foreign banks affect the competitive conditions of banking systems, with less emphasis on the relationship between bank competition and economic growth. There is also the PR H-statistics using the reduced form bank revenue equation (Panzar and Rosse, 1982, 1987). It measures the sum of the elasticities of the total revenue of the bank with respect to the bank's input prices.

\subsection{Stock Market Development and Economic Growth}

A well developed stock market encourage investment opportunities by recognizing and financing productive and viable projects that stimulate economic activity, mobilize domestic savings, allocate capital proficiency, help to diversify risks, and facilitate exchange of goods and services (Mishkin, 2001; Caporale, Howells and Soliman, 2004). Undoubtedly, stock markets are expected to increase economic growth by increasing the liquidity of financial assets, make global and domestic risk diversification possible, promote wiser investment decisions, and influence corporate governance, i.e., solving institutional problems by increasing shareholders' interest/value (Vector, 2005). In addition to the above, stock markets are best indicator to forecast future economic activity and describe actual causal affect between future economic growth and stock prices. On the contrary, the relationship between stock market development and real economic growth can be explained as any change in stock market which eventually changes the cost of rental capital. If the firms cost of borrowing will become high as compared to investment, it slows down the growth of the economy (Ahmed, Ali and Shahbaz, 2008).

\section{Research Methodology}

\subsection{Model and Data}

Our interest is to study the long-run relationship between economic growth and two financial sector indicators; bank competition and stock market development. We intuitively specify our model of interest as

$$
Y=\alpha+\beta_{1} M C_{t}+\beta_{2} B C_{t}+\beta_{3} C P S_{t}+\mu_{t}
$$

Where $Y_{t}$ is the real GDP growth, $M C_{t}$ is market capitalisation, $B C_{t}$ is bank competition, $C P S_{t}$ is Domestic bank credit as percent of GDP, $\mu_{t}$ is the error terms, $\alpha$ is the drift, $\beta_{1}, \beta_{2}, \beta_{3}$ are sensitivity of real GDP growth to $M C_{t}, B C_{t}$ and $C P S$ respectively.

\subsection{Stock Market Capitalisation Ratio (MC)}

Stock market Capitalisation ratio is the value of all listed share divided by GDP. The measure is considered as best measure of the stock market because it is less arbitrary (Demirguc-Kunt and Levine, 1996). The idea of this measure is the positive correlation with capital mobilisation and risk diversification on an economy-wide basis (Yartey, 2007).

$$
M C=\frac{\sum_{i=1}^{p} N_{i} V_{i}}{G D P}
$$

where $p$, is the number of listed companies, $N_{i}$ and $V_{i}$ are number and value of shares of $i^{\text {th }}$ listed company respectively. The stock market capitalisation used here is the market capitalisation of Ghana Stock Exchange (GSE) from 1991 to 2009 and obtained from Databank Research. 


\subsection{Bank Credit}

Bank Credit is the total credit provided by domestic banks divided by GDP. This is a control variable to capture the activity and efficiency of the banking sector in one of its functions-savings mobilisation and allocate funds to productive sectors of the economy. The selection is also motivated by the direct impact credit access has on economic growth. Easy access of funds by investors stimulates production in the private and public sectors, consequently increases growth in the GDP. Bank Credit were extracted from IMF-IFS Online Edition (2010) spanning between 1991 and 2009.

\subsection{Bank Competition}

The Herfindahl-Hirschman Index $(H H I)$ and Lerner Index are the two most commonly used proxy for Bank competition in the literature. We depart from the two proxies and use the sum number of banks operating in a particular year and time trend. The number of banks generates more competition in banks than sizes especially in services. Our proxy is computed as

$$
B C_{t}=\log n_{t}+\log T
$$

where $n$, is the number of registered banks in operation in year $\mathrm{t}$ and $T$ is the time trend. The number of bank registered in a particular year from 1992 to 2009 was obtained from Bank of Ghana various statistical Bulletin

All the data were obtain from World Bank Africa Economic Indicator except number of banks registered as at year $\mathrm{t}$ which was obtained from Bank of Ghana

\subsection{Method of Analysis}

The problem of non-stationarity of most of the economic time series which is likely to render standard ordinary least squares (OLS) estimator bias necessitated taking the first differences of the time series before implementing standard OLS. However, this may leads to the loss of information that is important for the long-run equilibrium. Cointegration approach has therefore been developed by Engle and Granger (1987) overcame this problem. According to this approach, there exist linear combination non-stationary time series which is stationary. Advances in econometrics have resulted in number of techniques in estimating cointegration equation (e.g. Engle and Granger (1987), Johansen(1995) Pessaran and Pessaran (2001), etc). The present study employs Autoregressive Distributed Lag (ARDL) model (Pesaran, Shin and smith, 2001) to test the presesence of cointegration. The ARDL model is generally specify as:

$$
\Delta Z=\alpha+\sum_{i=1}^{n} \beta_{i} \Delta Z_{t-i}+\sum_{i=0}^{p} \sum_{q=1}^{k} \gamma_{q i} \Delta X_{q t-i}+Z_{t-1}+\sum_{q=1}^{k} X_{q t-1}+Z_{t-1}+\mu_{t}
$$

Where

$\mathrm{Z}$ is the dependant variable; $\mathrm{X}$ is a vector of explanatory variables; $\mu_{t}$ is the error term and $\alpha$ is the constant term.

We estimate the cointegration relation with dynamic OLS proposed by Stock and Watson (1993) which corrects for possible simultaneity bias amongst the regressors. The DOLS has two desirable features which makes it appropriate for our study. The DOLS estimates long run equilibrium in systems which may involve variables integrated of different order but still cointegrated and has favourable performance as well in small samples. The DOLS used in this study follows Stock and Watson (1993):

$$
Z=\alpha+X^{\prime} \beta+\sum_{i=-p}^{p} \gamma \Delta X_{t+i}+\mu_{t}
$$

Where $p$ is the lag length within a relevant range to determine by some information criterion (AIC, BIC). Equation (5) is the DOLS regression. The DOLS specification removes the unit root component from the regression by simply adding leads and lags of the first difference of the explanatory variables to the OLS regression

Following the DOLS regression procedure, the equation (1) is specified below:

$$
\begin{aligned}
& Y=\alpha+\beta_{1} M C_{t}+\beta_{2} B C_{t}+\beta_{3} C P S_{t}+\beta_{4} \Delta M C_{t-1}+\beta_{5} \Delta M C_{t+1}+\beta_{6} \Delta B C_{t-1} \\
& +\beta \Delta B C_{t+1}+{ }_{6} \Delta C P S_{t-1}+\beta \Delta C P S_{t+1}+\mu_{t}
\end{aligned}
$$

Equation (6) is used to investigate the long run relationship between bank competition, stock market development and growth. 
We investigate the short run relationship through Granger causality based on base on error correction model. The Granger-causality is based on the regressions of the following form:

$$
\begin{aligned}
& \Delta Z_{t}=\sum_{i=1}^{n} \psi_{1 i} \Delta Z_{t-i}+\sum_{i=1}^{n} \omega_{1 i} \Delta X_{t-i}+\lambda_{1 i} \mu_{t-1}+\xi_{t} \\
& \Delta X_{t}=\sum_{i=1}^{n} \psi_{2 i} \Delta X_{t-i}+\sum_{i=1}^{n} \omega_{2 i} \Delta Y_{t-i}+\phi_{2 i} \mu_{t-1}+v_{t}
\end{aligned}
$$

In the above Granger-causality regression equations (7) and (8), X does not Granger-cause Z, if $\omega_{1 i}$ parameters are jointly zero, and $\mathrm{Z}$ does not Granger-cause $\mathrm{X}$, if $\psi_{2 i}$ parameters are jointly zero.

\section{Empirical Results and Analysis}

\subsection{Unit Root Test}

A necessary but not sufficient condition for cointegration is a test for unit root which was conducted using ADF test and $\mathrm{PP}$ test to all the variables in levels and in first difference.

Table 1 summarizes the results of the ADF and PP stationary tests. The null hypothesis tested is that the variable under study has a unit root against the alternative of no unit root. The lag-length is chosen using the Akaike Information Criterion. The results indicate that, the null hypothesis that the variables growth(Y), CPS, MC and BCP has a unit root cannot be rejected by both ADF and PP tests except for MC. However, after applying the first difference, both ADF and PP tests reject the null hypothesis. The results of both tests presented in table 1 concludes that all the variables are I (1) except MC which I (0). The implication is that the all the variables under consideration except market capitalization follows a random walk pattern, which possesses a purely nonpredictable component.

$<$ Table 1 about here>

\subsection{Causality Test}

Table 2 presents pairwise Granger-Causality test based on equations (8) and (9) to find the direction of causality. The null hypothesis of bank credit to private sector does not granger-cause economic growth could not be accepted at $5 \%$ significant level. However the null hypothesis of economic growth does not granger-cause bank credit to private sector cannot be rejected. The implication is that, there is a unidirectional causality from Bank credit to private sector to economic growth. A uni-directional causality running from banking competition and stork market capitalisation to economic growth is recorded at $5 \%$ significance level. We can argue that economic growth in Ghana is cause by the expansion and improvement in financial sector in the short run.

$<$ Table 2 about here $>$

\subsection{Long Run Relationship- ARDL and DOLS}

The existence of long run relationship among the variables is examined through ARDL Model estimation. The results of the unit root test allow us to implement ARDL model for $\mathrm{Y}_{\mathrm{t}}$ with intercept and no trend using the upper bound critical values reported in Pesaran et al. (2001) for determination of cointegration. The calculated F-statistics $F_{Y}(Y / B C, M C, C P S)=3.86$ for $A R D L(2,1,0,1)$ is higher than the upper bound critical value 3.67 at $5 \%$ significance level. This implies that there is cointegration relationship among the variables. The long run relationship is estimated using DOLS which add lead and lags of the difference of I(1) variables to the explanatory variables.

Table 3 shows that key regression statistics $R^{2}$ is high implying that overall goodness of fit of the

DOLS model is satisfactory. The cumulative sum of squares (CUSUMQ) plots (fig.1) from a recursive estimation of the model also indicates stability in the coefficients over the sample period. The results in Table 3 indicate banking competition has significant positive effect on economic growth in Ghana in the long run at 5\% significance level. It indicates that a unit increase in banking competition result in doubling of economic growth. The study also recorded positive and statistically significant response of economic growth to development in stock market at $10 \%$ significance level. Table 3 shows that $1 \%$ increase in stock market development leads to about $0.05 \%$ increase in economic growth; indicating stock market activities matter a little for economic growth in Ghana and consistent with Adam (2010) findings.

$<$ Table 3 about here $>$

$<$ Figure 1 about here $>$ 


\section{Conclusion}

Financial sector has an important role in economies. Competition and development in financial system means improving functions, which takes part in the financial system and consequently improve the allocation of resources which they collect from small depositors to investors. Competition in banking sector is likely to remove bottlenecks in the banking system, improve service to customers and thereby increasing in savings and efficient investments which will affect economic growth positively.

In literature, it is still in discussion that whether banking competition and stock market development affects economic growth. In this study, we analyse the effect of banking competition and stock market development on economic growth in Ghana. Short run analysis is done within the framework of Granger Causality while the long run analysis employed Autoregressive Distributed Lag (ARDL) and Dynamic OLS (DOLS) models. The study covers the period of 1992 to 2009.

The results show that banking competition and stock market development Granger Cause economic growth in Ghana. The long run estimation shows that banking competition is good for economic growth. We also recorded disproportionate response of economic growth to stock market development.

The implication of our finding is that policies that expand and improve competition in banking sector should be vigorously pursued.

\section{References}

Adam, A. M. (2010). Financial Sector Development and Economic Growth: An Empirical Analysis of the Case of Ghana. Lambert Academic Publishing, Germany

Ahmed, E. and Malik, A. (2009). Financial sector Development and Economic Growth Empirical Analysis of Developing Countries, Journal of Economic Cooperation and Development ,30,1 pp 17-40

Ahmed, N., Ali, L., and Shahbaz, M. (2008). Stock Market Development and Economic Growth: Ardl Causality in Pakistan. International Research Journal of Finance and Economics, Vol.14, pp.182-195.

Barro, R. J., (1997). Determinants of Economic Growth: A Cross-Country Empirical Study. MIT Press: Cambridge, MA.

Beck, T., (2008). Financial Dependence and International Trade. Review of International Economics, vol.11, pp.296-311. http://dx.doi.org/10.1111/1467-9396.00384

Bhide, A., (1993). The Hidden Costs of Stock Market Liquidity. Journal of Financial Economics vol.34, pp.31-51. http://dx.doi.org/10.1016/0304-405X(93)90039-E

Cao, M., and Shi, S. (2000). Screening, Bidding, and the Loan Market. Mimeo, Queen’s University.

Cetorelli, N., and Strahan, P. (2006). Finance as a Barrier to Entry: Bank Competition and Industry Structure in Local U.S. Markets. Journal of Finance.

Champonnois, S. (2007). Bank Competition and Development. Princeton University, retrieved in November, 2008 from [Online] Available: http//www. princeton.edu/thesis/pdf.

Claessens, S. and Laeven, L. (2005). Financial Dependence, Banking Sector Competition, and Economic Growth. World Bank Policy Research Working Paper 3481.

Claessens, S., and Laeven, L. (2003). Financial Development, Property Rights and Growth. Journal of Finance, vol.58, pp.2401-36. http://dx.doi.org/10.1046/j.1540-6261.2003.00610.x

Demirgüç-Kunt, A., and Maksimovic, V. (1998). Law, Finance and Firm Growth. Journal of Finance, vol.53, pp. 2107-37. http://dx.doi.org/10.1111/0022-1082.00084

Engle, R.W., and Granger, C.W.J. (1987). Cointegration and Error Correction: Representation, Estimation, and Testing. Econometrica, vol. 55, pp.251-76. http://dx.doi.org/10.2307/1913236

Granger, C. (1969). Investigating Causal Relations by Econometric Models and Crosss-pectral

Gregorio, J. D., and Guidotti, P. (1995). Financial Development and Economic Growth. World development, No.23, pp. 433-448. http://dx.doi.org/10.1016/0305-750X(94)00132-I

Jayaratne, J., and Strahan, P.E. (1996). The Finance-growth Nexus: Evidence from Bank Branch Deregulation. Quarterly Journal of Economics, vol.111, pp. 639-70. http://dx.doi.org/10.2307/2946668 
Kasekende, L. (2007). Financial Industry as a Catalyst for Economic Growth. Nigeria International Conference on Financial Sector Strategy, Abuja, June.

King, R. G., and Levine, R. (1993). Finance and Growth: Schumpeter Might be Right. Quarterly Journal of Economics, vol.108, pp.717-38. http://dx.doi.org/10.2307/2118406

Levine, R., and Zervos, S. (1998). Stock Markets, Banks, and Economic Growth. American Economic Review, vol. 88, pp.537-58.

Lucas, R.E. (1988). On the Mechanics of Economic Development. Journal of Monetary Economics vol.22, pp.3-42. http://dx.doi.org/10.1016/0304-3932(88)90168-7

McKinnon, R. I. (1973). Money and Capital Economic Development, Brookings Institution (Washington, D.C.).

Mishkin, F. S. (2001) The Economics of Money, Banking, and Financial Markets, $6^{\text {th }}$ ed.New York: Addison Wesley Longman.

Obstfeld, M. (1994). Risk-Taking, Global Diversification and Growth. American Economic Review.

Osei, V. (2005). Does the Stock Market Matter in Ghana? A Granger-Causality Analysis. Bank of Ghana, WP/BOG-05/13.

Pagano, M. (1993). Financial Markets and Growth. An Overview. European Economic Review, vol.37, pp. 613-622. http://dx.doi.org/10.1016/0014-2921(93)90051-B

Panzar, J. C., and Rosse, J. N. (1982). Structure, Conduct and Comparative Statistics. Bell Laboratories Economics Discussion Paper.

Pesaran, M. H., Shin, Y., and Smith, R. J. (2001). Bounds Testing Approaches to the Analysis of Level Relationships. Journal of Applied Econometrics 16: 289-326. http://dx.doi.org/10.1002/jae.616

Rajan, R., and Zingales, L. (1998). Financial Dependence and Growth. American Economic Review, vol. 88, pp.559-87.

Shaffer, S. (1989). Competition in the U.S. Banking Industry. Economics Letters, vol. 29, pp.321-323. http://dx.doi.org/10.1016/0165-1765(89)90210-3

Singh, A. (1997), Financial Liberalization, Stock Markets and Economic Development, The Economic Journal, vol.107, pp.771-82. http://dx.doi.org/10.1111/1468-0297.00192

Solow, R. M. (1956). A Contribution to the Theory of Economic Growth. Quarterly Journal of Economics, vol.70 (1), pp. 65-94, http://www.jstor.org/pss/1884513. http://dx.doi.org/10.2307/1884513

Table 1. Unit Root Test: ADF Test and PP-Test

\begin{tabular}{|c|c|c|c|c|c|}
\hline \multirow{2}{*}{ Variable } & \multicolumn{2}{|c|}{ ADF } & \multicolumn{2}{c|}{ PP } & \multirow{2}{*}{ Order of integration } \\
\cline { 2 - 5 } & Levels & $1^{\text {st }}$ Difference & Levels & $1^{\text {st }}$ Difference & \\
\hline$Y$ & $0.1983[0.7314]$ & $-7.0163[0.0000]^{* * *}$ & $-1.7911[0.3592]$ & $-6.9661[0.0000]^{* * *}$ & $\mathrm{I}(1)$ \\
\hline$C P S$ & $-1.5113[0.5052]$ & $-4.4749[0.0031]^{* * *}$ & $-1.5236[0.4992]$ & $-3.1578[0.0002]^{* * *}$ & $\mathrm{I}(1)$ \\
\hline$M C$ & $-3.1578[0.0400]^{* *}$ & - & $-3.1212[0.0429]^{* *}$ & - & $\mathrm{I}(0)$ \\
\hline$B C P$ & $-2.4281[0.1484]$ & $-3.1699[0.0401]^{* * *}$ & $-2.2171[0.20733]$ & $-3.2369[0.0354]^{* * *}$ & $\mathrm{I}(1)$ \\
\hline
\end{tabular}

Note: The null hypothesis for the PP and ADF test is that the data process under examination contains a unit root.). Critical values of PP \& ADF $1 \%$ and $5 \%$ are -3.43 and -2.86 respectively (see MacKinnon, 1996). * $(* * *)$ denotes rejection of the hypothesis at $10 \%(5 \%)$ significance level

Table 2. Granger-Causality Test Results: Economic Growth

\begin{tabular}{|l|l|c|}
\hline \multicolumn{1}{|c|}{ Null Hypothesis } & F-Statistic & Prob. \\
\hline Bank Credit does not Granger Cause Economic growth & $5.3358^{* * *}$ & 0.0144 \\
\hline Economic growth does not Granger Cause Bank Credit & 0.0962 & 0.9606 \\
\hline & & \\
\hline Bank Competition does not Granger Cause Economic growth & $4.6358^{* * *}$ & 0.0224 \\
\hline Economic growth does not Granger Cause Bank Competition & 0.6680 & 0.5877 \\
\hline Stock Market Capitalization does not Granger Cause Economic growth & $4.3093^{* * *}$ & 0.0279 \\
\hline Economic growth does not Granger Cause Stock Market Capitalization & 0.6084 & 0.6222 \\
\hline
\end{tabular}

$*(* * *)$ denotes rejection of the hypothesis at 10\% (5\%) significance level 
Table 3. Stock-Watson Dynamic OLS Long Run Estimates of Economic Growth

\begin{tabular}{|c|l|l|l|}
\hline Dep Var. & coefficient & t-statistic & P-value \\
\hline BCP & $2.044412^{* *}$ & 6.239479 & 0.0008 \\
\hline CPS & 0.000622 & 0.016261 & 0.9876 \\
\hline MC & $0.051741^{*}$ & 2.238072 & 0.0665 \\
\hline D(GROWTH(1)) & $-0.421540^{* *}$ & -4.366979 & 0.0047 \\
\hline D(MC(1)) & $0.045052^{*}$ & 1.965129 & 0.0970 \\
\hline C & $-8.621705^{* *}$ & -8.756175 & 0.0001 \\
\hline R2 & 0.94 & Sum squared resid & 0.91 \\
\hline F-Statistic & 11.45 & DW & 2.1 \\
\hline
\end{tabular}

$*(* *)$ denotes rejection of the hypothesis at $10 \%$ (5\%) significance level



Figure 1. CUSUM of Squares Plot 